\title{
アルミニウム並びにアルミニウム合金の前処理と直接メッキ
}

\author{
金 沢 純 一*
}

\section{Studies on Direct Electro-Plating and Surface Treatment of Aluminium and Aluminium Alloy}

\author{
Junichi KANAZAWA
}

The electro-plating of aluminum and its alloy has been so far considered to be hard. To get over this difficulty, the two studies were carried out, one of which was the treatment by conc. $\mathrm{HNo}_{3}$, and the other zincate. In this study, after reviewing the above-mentioned methods, the author found out that the former was better when treated for a long time than for a short time, and the manganate processes, was also as good as in the case of chromate. The same result was also obtained by treating after the electro-polishing.

\section{I 緒 論}

アルミニウム招よびその合金へのメッキは從来困難と されていた。この困難さを克服するため前処理沠の研究 が行われてきた。その一は濃硝酸処理沠であり，その二 は金属酸塩処理法である。亜鉊酸塩処理については1951 年米国材料試験協会が既に推奖している。本研究では㕣 鉊酸塩以外の金属酸塩処理法を見出そうとした。その結 果マンガン・クロム酸塩処理もまたすぐれた前処理液で あるととがわかった。すなわちアルミニウムへのニッケ ルメッキでは, マンガン酸塩処理が西鉛酸塩処理より光 沢にすぐれたメッキが得られ, ジェラルミン・ESDへの メッキではマンガン・クロム酸塩処理が西鉊酸塩処理と 同樣な良好メッキが得られる。第三の処理法は電解研磨 後金属酸塩処理法である。この方法によるとさは金属酸 塩処理法による場合より一㬝光沢にすぐれたメッキが得 られるのみでなく,メッキ時間が極めて短縮される。乙 の処理法です亜鉊酸塩の外にクロム・マンガンの金属酸 塩がすぐれた結果を示す。

以上の三処理法についてその優劣をみると第 1 よりは 第2,さらに第 3 とよい結果を示している。これらの処理 とメッキの機構については最後に簡単な考祭を試みた。

1 実験材料およびその成分

\begin{tabular}{|c|c|c|c|c|c|c|c|c|}
\hline 材 料 成分(\%) & $\mathrm{Si}$ & $\mathrm{Fe}$ & $\mathrm{Cu}$ & $\mathrm{Mg}$ & Mn & $\mathrm{Zn}$ & $\mathrm{Cr}$ & $\mathrm{Al}$ \\
\hline アルミニウム & $0.10 \mathrm{C}$ & 0.22 & 0.09 & 0.04 & - & - & - & 残部 \\
\hline シュラルミン & 0.100 & 0.77 & 4.27 & 0.70 & - & 一 & - & 残部 \\
\hline E $\quad$ S $\quad$ D & 0.34 & 一 & 2.42 & 1.33 & 0.187 & 7.12 & 0.13 & 残部 \\
\hline
\end{tabular}

* 熊谷女子高等学校

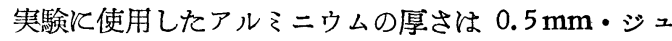
ラルミン・ESD の厚さは $1 \mathrm{~mm}$ で大きさは何れる $20 x$ $25 \mathrm{~mm}$ のものである。

2 メッキ液招よび処方

単体メッキそして銅・ニッケル・合金メッキとして真 鍮・青銅を選んだ。メッキ液は普通メッキ液を用いた。

a 銅メッキ夜

\begin{tabular}{|c|c|c|c|}
\hline $\mathrm{CuCN}$ & $11.3 \mathrm{~g}$ & S.G & 1.07 \\
\hline $\mathrm{NaCN}$ & $17.0 \mathrm{~g}$ & \multicolumn{2}{|c|}{$\mathrm{pH} 9.6$ 以上 } \\
\hline $\mathrm{Na}_{2} \mathrm{CO}_{3}$ & 7.5 & 水 & $500 \mathrm{~g}$ \\
\hline \multicolumn{4}{|c|}{$\mathrm{b}$ ニッケルメッキ液 } \\
\hline \multicolumn{2}{|c|}{$\mathrm{Ni}\left(\mathrm{NH}_{4}\right)_{2}\left(\mathrm{SO}_{4}\right)_{2} \cdot 6 \mathrm{H}_{2} \mathrm{O}$} & $37.5 \mathrm{~g}$ & S. G1.14 \\
\hline \multicolumn{2}{|c|}{$\mathrm{NH}_{4} \mathrm{Cl}$} & 7.5 & $\mathrm{pH} 9.6 \mathrm{D}$ \\
\hline \multicolumn{2}{|l|}{$\mathrm{H}_{3} \mathrm{BO}_{3}$} & 7.5 & \\
\hline \multicolumn{2}{|l|}{ 水 } & 500 & \\
\hline \multicolumn{4}{|c|}{ c 真鍮メッキ液 } \\
\hline $\mathrm{CuCN}$ & $30 \mathrm{~g}$ & S. G & 1.12 \\
\hline $\mathrm{Zn}(\mathrm{CN})_{2}$ & 7.5 & $\mathrm{pH}$ & 9.6以上 \\
\hline $\mathrm{NaCN}$ & $45.5 \mathrm{~g}$ & $\mathrm{Na}_{2} \mathrm{CO}_{3}$ & $15.0 \mathrm{~g}$ \\
\hline 水 & 500 & & \\
\hline
\end{tabular}

d 青銅メッキ液

$\begin{array}{llll}\mathrm{CuCN} & 18.8 \mathrm{~g} & \mathrm{~S} . \mathrm{G} & 1.12 \\ \mathrm{Na}_{2} \mathrm{SnO}_{3} & 14.8 & \mathrm{pH} & 9.6 \text { 以上 } \\ \mathrm{NaCN} & 28.1 & \text { 水 } & 500 \mathrm{~g}\end{array}$

$3 メ ッ キ$ 結果試験

a 剝離試験，メッキした材料を万力に挾み直角に曲 げて别離しない場合を 1 回とかぞえ, 元の状態に復して 2 回,さらに反対に曲げて涂離した場合を 3 回として制 離の強弱の度合を表した。アルミニウムでは 4 回で材料 が破れ, シュラルミン・ESDでは 1 回で破壊した。若し 直角に曲げる以前に䡈離を生じた時は曲げた角度で示し 
た。

b ピンホール試験，飽和食塩水飞24時間浸清し，そ の表面飞生ずる水酸化アルミニウムの白色綿状の斑点を $1 \mathrm{~cm}^{2}$ 当りの数によって表した。

c 光沢試験, 全く肉眼によった。

d その他，陽極板は方販の電気銅板，ニッケル板， 真鍮（四六真鍮）,青銅をメッキ板と同等の大きさとして 用いた。アルミニウム・ジェラルミン等のメッキ時のホ ルダーはアルミニウムピンセットを使用した。

\section{B メッキ方法}

\section{I 濃 硝 酸処理法}

実験方法，アルミニウム・ジュラルミン・ESD を熱芘 性ソーダ液江浸清し盛に水素が発生した時取り出し水洗 いせず直ちと濃硝酸(比重1.42)中飞入れ 1 12時閒浸漬 し，水洗してメッキした。一般飞短時間濃硝酸処理より 長時間処理の場合良好メッキが得られる。

a 銅メッキ

アルミニウムおよび ESD は浴温度・電流密度・メッ キ時間の如何にかかわらずブッを生じ易く，30の曲げ 汶対して剩離し易い。ジラルミンは10時間濃硝酸処理 の場合相当よいメッキができるように見えるがピンホー ルが多い。濃硝酸処理では満足すべきメッキは得られな W。

$\mathrm{b}$ ニッケルメッキ

濃硝酸処理時間とニッケルメッキ

\begin{tabular}{|c|c|c|c|c|c|c|c|c|c|c|c|}
\hline \multicolumn{3}{|c|}{ メッキ条件 浴温度 } & \multicolumn{3}{|c|}{$10^{\circ}$} & \multicolumn{3}{|c|}{$30^{\circ}$} & \multicolumn{3}{|c|}{$50^{\circ} \mathrm{C}$} \\
\hline $\begin{array}{l}\text { 電流 } \\
\text { 密度 }\end{array}$ & $\begin{array}{l}\text { 䟴硝酸 } \\
\text { 処 理 }\end{array}$ & $\begin{array}{l}x ッ キ \\
\text { 特 間 }\end{array}$ & $\mathrm{Al}$ & $\mathrm{D}$ & $\begin{array}{l}\mathrm{E} \\
\mathrm{S} \\
\mathrm{D}\end{array}$ & & $\mathrm{D}$ & $\begin{array}{l}\mathrm{E} \\
\mathrm{S} \\
\mathrm{D}\end{array}$ & $\mathrm{A} 1$ & $\mathrm{D}$ & $\begin{array}{l}\mathrm{E} \\
\mathrm{S} \\
\mathrm{D}\end{array}$ \\
\hline \multirow[t]{2}{*}{0.75} & 5 時 & 40分 & x & $\times$ & $x$ & $x$ & $x$ & $x$ & $x$ & $x$ & $\times$ \\
\hline & 10 & " & $\times$ & $x$ & $x$ & $x$ & $\times$ & $\times$ & $x$ & $x$ & $x$ \\
\hline \multirow[t]{2}{*}{1.00} & 5 & " & $x$ & $\times$ & $x$ & $x$ & $\times$ & $x$ & $x$ & $\times$ & $\times$ \\
\hline & 5 & 40 & $x$ & $x$ & $x$ & $\times$ & 0 & 0 & $x$ & 0 & $\bigcirc$ \\
\hline \multirow[t]{2}{*}{1.25} & 7 & " & x & $x$ & $x$ & $x$ & 0 & 0 & $x$ & 0 & 0 \\
\hline & 10 & " & $\times$ & $x$ & $x$ & $\bigcirc$ & 0 & 0 & 0 & 0 & 0 \\
\hline \multirow{2}{*}{$\begin{array}{l}2.5 \\
\mathrm{~A} / \mathrm{dm}^{2}\end{array}$} & 5 & 40 & $\times$ & $\times$ & $\times$ & $x$ & $\bigcirc$ & $\bigcirc$ & $x$ & 0 & 0 \\
\hline & 10 & 40 & $x$ & $x$ & $x$ & 0 & 0 & $\bigcirc$ & 0 & 0 & 0 \\
\hline
\end{tabular}

灌硝酸処理とメッキ試験結果

\begin{tabular}{|c|c|c|c|c|}
\hline 類 & $\begin{array}{l}\text { 濃碚酸処 } \\
\text { 理 時 間 }\end{array}$ & 光 沢 & 曲げ剝離 & ピンホール \\
\hline 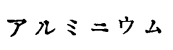 & 10 & よい & $25^{\circ}$ & 0 \\
\hline \multirow{2}{*}{ ジュラルミン } & 5 & 56 & $30^{\circ}$ & 0.1 \\
\hline & 10 & やや暗い & $45^{\circ}$ & 0 \\
\hline \multirow{2}{*}{ E $\quad \mathrm{S} \quad \mathrm{D}$} & 5 & よい & $30^{\circ}$ & 0.2 \\
\hline & 10 & やや暗い & $45^{\circ}$ & 0 \\
\hline
\end{tabular}

ニッケルメッキではアルミニウム・ジュラルミン・

$\mathrm{ESD}$ 共浴温度 $30^{\circ} \mathrm{C}$ 以上で10時間処理がよい。
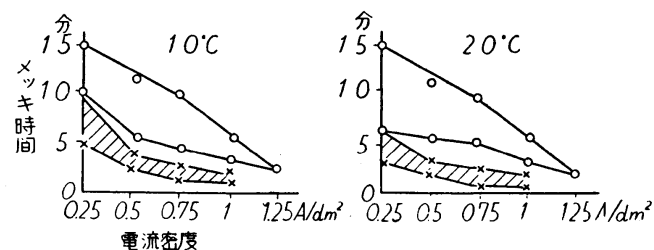

第1図 ジュラルミンの長短処理と鍍着範囲 (浴温度 $10^{\circ} \sim 20^{\circ} \mathrm{C}$ )

斜線の範囲は短時間処理，白線の範囲は長時間 処理，長時間処理の方が広く安定している

ESD とも長時間処理で満足すべき光沢メッキが得られ る。アルミニウムでは $10^{\circ} \mathrm{C}$ 以下の低温では濃硝酸処理時 間の如何にかかわらず光沢メッキは得られない。 $30^{\circ} \mathrm{C}$ 以 上，10時間処理で光沢メッキが得られるようになる。シ ニラルミン・ESD では 5 時間以上でメッキが得られるが 10時間処理の方が曲げ剩離に強く，ピンホールのないメ ッキが得られる。

\section{シュラルミンの濃硝酸処理と剝離試験}

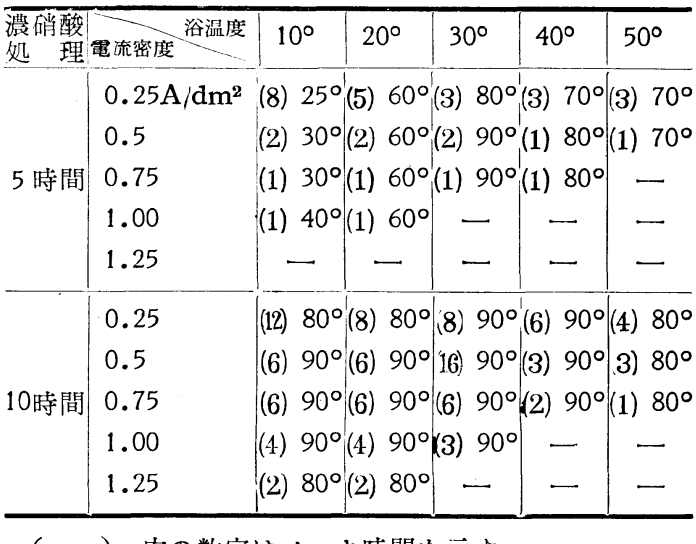

ジュラルミンの蕽硝酸処理とピンホール試験

\begin{tabular}{|c|c|c|c|c|c|c|}
\hline \multicolumn{2}{|c|}{ 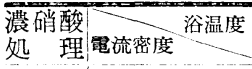 } & $10^{\circ}$ & $20^{\circ}$ & $30^{\circ}$ & $40^{\circ}$ & $50^{\circ} \mathrm{C}$ \\
\hline \multirow{5}{*}{5 時間 } & $0.25 \mathrm{~A} / \mathrm{dm}^{2}$ & 1.5 & 1.5 & 1.2 & 0.5 & 1.0 \\
\hline & 0.5 & 1.5 & 1.2 & 0.5 & 0.7 & 1.1 \\
\hline & 0.75 & 1.6 & 1.4 & 1.0 & 1.3 & - \\
\hline & 1.00 & 1.7 & 1.4 & - & & - \\
\hline & 1.25 & - & - & - & & - \\
\hline \multirow{5}{*}{ 10時間 } & 0.25 & 1.1 & 1.0 & 1.0 & 0.2 & 0.4 \\
\hline & 0.5 & 1.0 & 0.4 & 0 & 0.1 & 0.3 \\
\hline & 0.75 & 1.3 & 0.4 & 0 & 0.3 & 0.6 \\
\hline & 1.00 & 1.5 & 0.9 & 0.3 & 一 & - \\
\hline & 1.25 & 1.7 & 1.3 & 一 & - & 一 \\
\hline
\end{tabular}


メッキ結果, 浴温度 $40^{\circ} \mathrm{C}$ 電流密度 $1.9 \mathrm{~A} / \mathrm{dm}^{2}, \times ッ キ$ 時間40分でえられた光沢メッキについて武験した結果, アルミニウムでは $25^{\circ} て ゙$ 制離するがピンホールは全然認 められない。シュラルミン, ESDは10時間処理では光沢 がやや暗いが曲げ剩離・ピンホールにすぐれたメッキが えられる。5時間処理の場合は剩離・ピンホールと括い てやや劣る。すなわち10時間処理の方が 5 時間処理より よいメッキが得られる。

\section{c 真鍮メッキ}

アルミニウム注長短濃硝酸処理いづれの場合す良好な メッキがえられない。ジュラルミン・ESDでは5時間濃硝 酸処理で良好なメッキがえられる。また短時間, 長時間 処理について鍍着範囲をるると, 短時間処理では速やか そメッキがえられるがブツを生じ易く,剩離し易い。ピン ホールの数るやや多い光沢は長時間処理よりる明るい。

メッキ時間の安定性娳離試験・ピンホール試験の結果 より長時間濃硝酸処理が短時間処理より遙かとよく浴温 度 $30^{\circ} \mathrm{C}$. 電流密度が $0.5 \sim 0.75 \mathrm{~A} / \mathrm{dm}^{2}$ で最も良好なメッ キがえられる。

ESDではジュラルミンとほぼ同樣の結果であるがピン ホール皆無のメッキはえられない。

d 青銅メッキ

真鍮メッキの場合とほとんぞ同梯結果をえた。すなわ 亜塩酸塩液の処方と亜鉛の析出

\begin{tabular}{|c|c|c|c|c|c|c|}
\hline 処 & 方 種 & A & B & $\mathrm{C}$ & D & $\mathrm{E}$ \\
\hline & $\mathrm{Zn} \mathrm{O}$ & $5 \mathrm{~g} / l$ & $10 \mathrm{~g} / l$ & $15 \mathrm{~g} / l$ & $25 \mathrm{~g} / l$ & $50 \mathrm{~g} / l$ \\
\hline & $\mathrm{NaOH}$ & 45 & 45 & 45 & 50 & 50 \\
\hline & $\frac{\mathrm{Zn} \mathrm{O}}{\mathrm{NaOH}}$ & $\begin{array}{l}1 \\
9\end{array}$ & $\frac{1}{4.5}$ & $\frac{1}{3}$ & $\begin{array}{c}1 \\
-1\end{array}$ & 1 \\
\hline
\end{tabular}

Znの析出 不均一飞析出 均一に析出
アルミニウム処理の浴温度、電流密度とメッキ範囲

\begin{tabular}{|c|c|c|c|c|c|}
\hline 処 理 & 電流密度 & 0.25 & 0.5 & 0.75 & $1 \mathrm{~A} / \mathrm{dm}^{2}$ \\
\hline & $10^{\circ} \mathrm{C}$ & 10-25分 & 4-8分 & $3-4$ 分 & 2 分 \\
\hline マンガン & 20 & $5-25$ & $3-6$ & $3-6$ & $\times$ \\
\hline \multirow[t]{3}{*}{ 酸 } & 30 & $5-10$ & $3-6$ & 3 & $\times$ \\
\hline & 40 & $3-7$ & $2-3$ & $x$ & $\times$ \\
\hline & $10^{\circ} \mathrm{C}$ & 12-25分 & $5-7$ 分 & $2-3$ 分 & 2 分. \\
\hline 鉛 & 20 & $6-26$ & $3-7$ & $3-6$ & $\times$ \\
\hline \multirow[t]{2}{*}{ 酸 } & 30 & $6-12$ & $3-7$ & 3 & $x$ \\
\hline & 40 & $3-8$ & $2-3$ & $x$ & $\times$ \\
\hline
\end{tabular}

マンガン、亜鉛酸塩処理の比較（）内はメッキ時間

\begin{tabular}{|c|c|c|c|c|c|}
\hline $\begin{array}{l}\text { 処 } \\
\text { 理 }\end{array}$ & 試験 & ${ }^{10}(6)$ & ${ }^{20}(5)$ & ${ }^{30}(5)$ & $40^{\circ} \mathrm{C}_{(3)}$ \\
\hline $\begin{array}{l}\nabla \\
\text { ン } \\
\text { ガ } \\
\text { ン } \\
\text { 酸 } \\
\text { 塩 }\end{array}$ & $\begin{array}{l}\text { 光 沢 } \\
\text { 剝 離 } \\
\text { ピンホール }\end{array}$ & $\begin{array}{l}\text { よい } \\
1 \text { 回 } \\
5\end{array}$ & $\begin{array}{l}\text { よい } \\
1 \text { 回 } \\
3.8\end{array}$ & $\begin{array}{l}\text { よい } \\
1 \text { 回 } \\
2.5\end{array}$ & $\begin{array}{l}\text { よい } \\
1 \text { 回 } \\
3.8\end{array}$ \\
\hline $\begin{array}{l}\text { 亜 } \\
\text { 鉛 } \\
\text { 酸 } \\
\text { 塩 }\end{array}$ & $\begin{array}{lr}\text { 光 沢 } \\
\text { 剩 } \\
\text { ピンホー 離 }\end{array}$ & $\begin{array}{c}\text { やや暗い } \\
4 \text { 回 } \\
5\end{array}$ & $\begin{array}{l}\text { よい } \\
4 \text { 回 } \\
1.1\end{array}$ & $\begin{array}{l}\text { よい } \\
4 \text { 回 } \\
0\end{array}$ & $\begin{array}{l}\text { よい } \\
3 \text { 回 } \\
3\end{array}$ \\
\hline
\end{tabular}

（）内はメッキ時間分を示す、電流密度 $0.5 \mathrm{~A} / \mathrm{dm}^{2}$

ちアルミニウムは濃硝酸処理では満足すべきメッキは得 られないが, ジュラルミン, ESD では短時間処理の場 合, $30 \sim 40^{\circ} \mathrm{C}, 0.25 \sim 0.75 \mathrm{~A} / \mathrm{dm}^{2}$ でメッキ時間が $2 \sim 5$ 分でメッキがえられ長時間処理の場合は 3〜15分とメッ キ時間が長くなっている。しかしジュラルミン, ESDと もピンホール皆無のメッキはえられない。

\section{II 金属酸塩処理法}

各種金属酸塩処理と実験結果（金属酸塩名を金属酸化物で表した）

\begin{tabular}{|c|c|c|c|c|c|c|c|c|c|c|c|c|}
\hline 種類 & メッキ & & 属酸 & 化物 & $\mathrm{MnO}_{2}$ & $\mathrm{ZnO}$ & $\mathrm{Cr}_{2} \mathrm{O}_{3}$ & $\mathrm{Cr} \mathrm{O}_{3}$ & $\mathrm{Fe}_{2} \mathrm{O}_{3}$ & $\mathrm{SnO}_{2}$ & $\mathrm{~Pb}_{2} \mathrm{O}_{4}$ & $\mathrm{Cu} \mathrm{O}$ \\
\hline \multirow{4}{*}{$\begin{array}{l}\boldsymbol{\gamma} \\
\pi \\
\Sigma \\
= \\
ウ \\
\Delta\end{array}$} & 銅 & \multirow{4}{*}{ ッ } & \multirow{4}{*}{ ケ } & \multirow[b]{2}{*}{$\pi$} & 0 & (a) & $x$ & $\times$ & $x$ & $\times$ & $\times$ & $x$ \\
\hline & $=$ & & & & (a) & (a) & $x$ & $x$ & $\times$ & $\times$ & $\times$ & $x$ \\
\hline & 真 & & & 鍮 & 0 & (a) & $x$ & $\times$ & $\times$ & $\times$ & $\times$ & $\times$ \\
\hline & 青 & & & 銅 & $x$ & (O) & $x$ & $\times$ & $\times$ & $\times$ & $\times$ & $x$ \\
\hline ジ & 銅 & & & & 0 & (a) & $\times$ & $x$ & $\times$ & $\times$ & $\times$ & $x$ \\
\hline$\frac{7}{\bar{y}}$ & $=$ & ッ & ケ & $n$ & (a) & (a) & (2) & $\times$ & $\times$ & $x$ & $x$ & $\times$ \\
\hline$\pi$ & 真 & & & 鍮 & (a) & (a) & (D) & $\times$ & $\times$ & $x$ & $\times$ & $\times$ \\
\hline ע & 青 & & & 銅 & 0 & (a) & (a) & $\times$ & $\times$ & $x$ & $\times$ & $\times$ \\
\hline E & 銅 & & & & (a) & (a) & (a) & $\times$ & $\times$ & $\times$ & $\times$ & $x$ \\
\hline $\mathrm{S}$ & $=$ & \% & ケ & $r$ & (a) & (a) & (a) & $x$ & $\times$ & $\times$ & $\times$ & $x$ \\
\hline & 真 & & & 鍮 & $\times$ & (a) & (a) & $\times$ & $\times$ & $\times$ & $\times$ & $x$ \\
\hline D & 青 & & & 銅 & $\times$ & (a) & $x$ & $\times$ & $\times$ & $x$ & $x$ & $x$ \\
\hline
\end{tabular}

ASTM では市販カセイソー ダ $\left(76 \% \mathrm{Na}_{2} \mathrm{O}, 525 \mathrm{~g} / l\right)$, 酸化亜 鉛200g/lにアルミニウムを浸清 するととを奖めている。本研究 では酸化覀鉊以外の金属酸化物 $\mathrm{MnO}_{2}, \mathrm{Cr}_{2} \mathrm{O}_{3}, \mathrm{CrO}_{3}, \mathrm{Fe}_{2} \mathrm{O}_{3}$, $\mathrm{SnO}_{2}, \mathrm{~Pb}_{3} \mathrm{O}_{4}, \mathrm{CuO}$ 等の酸化物 とカセイソーダで金属酸塩を造 って熱カセイソーダ処理したア ルミニウムを15〜35秒漫漬し水 洗い後メッキした。ジュラル之 ン, ESD は熱カセイソーダ中 その合金である鉄, 銅等の酸化 物のため黒色になるので, これ を濃硝酸中に漫清して酸化物を 
ESDえの三処理と埕メッキ $\mathrm{Dk}=0.5 \mathrm{~A} / \mathrm{dm}^{2}$

\begin{tabular}{|c|c|c|c|c|c|}
\hline 処 理 & 試験 浴温度 & $10^{\circ}$ & $20^{\circ}$ & $30^{\circ}$ & $40^{\circ} \mathrm{C}$ \\
\hline マンガン & 光 沢 & よと & & よい(28) & よい(23) \\
\hline & 剝 & 1 回 & 1 回 & 1 回 & 1 回 \\
\hline & ピンホール & 3.2 & 1.3 & 0 & 5 \\
\hline 鉛 & & $\begin{array}{r}\text { (25) } \\
\text { やや暗い }\end{array}$ & やや暗い & よい & よい(15) \\
\hline & 刎 & 1 回 & & 1 回 & 1 回 \\
\hline 瑥 & ピンホール & & 1 & 0 & 0 \\
\hline \multirow{2}{*}{$ク$} & 光 & よい(35) & よい & よい(25) & よい(25) \\
\hline & 剝 & 1 回 & 1 回 & 1 回 & 1 回 \\
\hline & ピンホール & 2.8 & 1.3 & 0.1 & 6 \\
\hline
\end{tabular}

（）内はメッキ時間分を示す。

溶解し去った後水洗し, 金属酸塩処理して⿱亠凶ッキした。

a 各種金属酸塩処理液の調製と予備実験

1 西鉊酸塩液の調製と业鉊の析出

酸化亜鉊とカセイソーダを以下に述べるように調製し その中にアルミニウムを浸漬して亚鉊の析出状態を調べ た。

\section{2 亜鉊酸塩以外の金属酸塩の調製}

前実験の結果に基づき金属酸化物とカセイソーダとの
比を $25 \mathrm{~g} / l \cdot 50 \mathrm{~g} / l$ 飞調合した。

3 各種金属酸塩処理と予借実験

メッキ条件, 室温, 電流密度 $0.5 \mathrm{~A} / \mathrm{dm}^{2}$ メッキ時間 任意

以上の結果より一般にマンガン, 亜鉊，クロム酸塩処 理が度好である。

a 銅メッキ

1) アルミニウムへのメッキ・浴温度 $10 \sim 40^{\circ} \mathrm{C}$, 電 流密度0.25〜 1.0A/ $\mathrm{dm}^{2}$ に打けるメッキ時間ではマンガ ン, 亜鉛酸塩ともほぼ同柡であるがメッキ結果では亜鉊 酸塩処理の方が遙か、すぐれている。特に $30^{\circ} \mathrm{C}, 0.5 \mathrm{~A} /$ $\mathrm{dm}^{2}$ では理想的なメッキがえられる。

2) ジェラルミン, ESDへのメッキ

ジュラルミンにはマンガン, 亜鉊酸塩処理とも良好メ ッキがえられる。しかし亜鉊酸塩処理は剝離, ピンホー ルにマンガン酸塩処理よりすぐれたメッキをうる。 ESD へのメッキではマンガン, 亜鉊, クロム酸塩処理とも全 く同樣のメッキをうるととができる。

$\mathrm{b}$ ニッケルメッキ

ニッケルメッキでは銅メッキと同じようにアルミニウ ムにはマンガン, 亜鉊酸塩, ジュラルミンにはマンガン, 亜鉊，クロムの三処理液がよい。ESD \&ジュ ラルミンと同梯である。メッキ時間を比較す るとマンガン，クロム酸塩処理の方が亜鉛酸 塩より安定性をもっている。結果試験に打い ては優劣が皃とんど見あたらない。

c 青銅メッキ

アルミニウム, $\mathrm{ESD}$ には雨鉊酸塩処理のみ がよく, シュラルミンにはマンガン冓鉊・ク ロム酸塩がよかった,アルミニウム ESDの西 鉛酸塩処理ではアルミニウムの方が制離・ピ ンホール光沢に遙がすぐれている。しかし 両者とも $30^{\circ} \sim 40^{\circ} \mathrm{C}, 0.25 \sim 0.75 \mathrm{~A} / \mathrm{dm}^{2}$ でメ ッキするときはピンホール皆無のメッキがえ

第2図ジュラルミンへの三処理とメッキ範国 $\left(20^{\circ}\right.$ 及び $30^{\circ} \mathrm{C}$

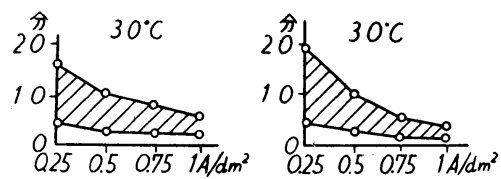

メ $ッ$

\begin{tabular}{|c|c|c|c|c|c|c|c|c|c|c|c|c|c|c|}
\hline メッキ & - 銅 & \multicolumn{2}{|c|}{$ッ$ キ } & \multicolumn{3}{|c|}{ ニッケルメッキ } & \multicolumn{4}{|c|}{ 真 鍮 メッキ } & \multicolumn{4}{|c|}{ 青 銅 メッキ } \\
\hline 類 & $\begin{array}{l}\text { 順 } \\
\text { 位 }\end{array}$ & $\begin{array}{l}\text { 属 } \\
\text { 塩 }\end{array}$ & 適 & $\begin{array}{l}\text { 順 } \\
\text { 位 }\end{array}$ & $\begin{array}{ll}\text { 金 } & \text { 属 } \\
\text { 酸 } & \text { 聕 } \\
\end{array}$ & $\begin{array}{l}\text { 適 } \\
\text { 否 }\end{array}$ & $\begin{array}{l}\text { 順 } \\
\text { 位 }\end{array}$ & $\begin{array}{ll}\text { 金 } \\
\text { 酸 }\end{array}$ & $\begin{array}{l}\text { 属 } \\
\text { 塩 }\end{array}$ & $\begin{array}{l}\text { 適 } \\
\text { 否 }\end{array}$ & $\begin{array}{l}\text { 順 } \\
\text { 位 }\end{array}$ & 金 & $\begin{array}{l}\text { 属 } \\
\text { 塩 }\end{array}$ & $\begin{array}{l}\text { 適 } \\
\text { 否 }\end{array}$ \\
\hline \multirow{2}{*}{ アルミニシム } & 1 & 亜 鉛 & (a) & 1 & \multirow{2}{*}{$\begin{array}{l}\text { マンガン } \\
\text { 亜 鉛 }\end{array}$} & (a) & 1 & \multirow{2}{*}{\multicolumn{2}{|c|}{$\begin{array}{l}\text { 亚 鉛 } \\
\text { マンガン }\end{array}$}} & (O) & 1 & \multirow[t]{2}{*}{ 亜 } & \multirow[t]{2}{*}{ 鉛 } & \multirow[t]{2}{*}{ (a) } \\
\hline & 2 & マンガン & $\bigcirc$ & 1 & & (a) & 2 & & & (C) & & & & \\
\hline \multirow{3}{*}{ ジェラルミン } & 1 & 亚鉛 & (C) & 1 & マンガン & (a) & 1 & \multicolumn{2}{|c|}{ マンガン } & (a) & 1 & \multirow{2}{*}{\multicolumn{2}{|c|}{$\begin{array}{l}\text { 亜 鉛 } \\
\text { マンガン }\end{array}$}} & (2) \\
\hline & 1 & マンガン & (C) & 1 & 亜 鉛 & (C) & 1 & 亜 鋅 & 鉛 & (a) & 2 & & & 0 \\
\hline & 1 & ク口 ム & (a) & 1 & クロ ム & (C) & 1 & ク口 & ム & (a) & 2 & ク ロ & 厶 & O \\
\hline \multirow{3}{*}{ E $\quad \mathrm{S} \quad \mathrm{D}$} & 1 & 亜鉛 & (a) & 1 & 亜 & (C) & 1 & \multicolumn{2}{|c|}{ マンガン } & $\bigcirc$ & 1 & 亜 & 鉛 & (a) \\
\hline & 1 & マンガン & (O) & 1 & マンガン & (a) & 1 & 垔金 & 鉛 & O & & & & \\
\hline & 1 & ク口 ム & (O) & 1 & ク口ム & (C) & 1 & ク & ム & 0 & & & & \\
\hline
\end{tabular}

青銅メツキ 
Vol. 7, No. 7, 1956 アルミニウムとアルミニウム合金の前処理と直接メッキ

られる。シュラルミンと対す る三処理液で汇覀鉊酸塩処理! が最もよくマンガン，クロム が同程度によい。

$\mathrm{d}$ 金属酸塩処理と適否の 順位

III 電解研磨・金属酸塩処 理法

水洗い後 $\mathrm{H}_{3} \mathrm{PO}_{4}$ (比重1.30)

\begin{tabular}{|c|c|c|c|c|c|c|c|c|}
\hline 処 理 & 試験 & 金属酸堆| & $\mathrm{Mn} \mathrm{O}_{2}$ & $\mathrm{ZnO}$ & $\mathrm{Cr}_{2} \mathrm{O}_{3}$ & $\mathrm{Fe}_{2} \mathrm{O}_{3}$ & $\mathrm{~Pb}_{3} \mathrm{O}_{4}$ & $\mathrm{CuO}$ \\
\hline \multirow{3}{*}{ 水洗い } & 光 & 沢 & よい & よい & よい & よい & よい & よい \\
\hline & 剩 & 離 & 3.5回 & 3.5回 & 3.5回 & 2 回 & ·30回 & 1 回 \\
\hline & & 小ール & 0.1 & 0 & 1.5 & 2.1 & 3 & 3 \\
\hline \multirow{3}{*}{$\begin{array}{l}\text { 熱か性 } \\
\text { ソーダ }\end{array}$} & 光 & 沢 & 暗い & やや暗い & $x$ & $x$ & $x$ & $x$ \\
\hline & 剥 & 離 & 4 回 & 4 回 & $x$ & $x$ & $x$ & $x$ \\
\hline & & ホーール & 0.1 & 0 & $x$ & $x$ & $x$ & $x$ \\
\hline
\end{tabular}

メッキ条件 溶温度 $20^{\circ} \mathrm{C} \quad \mathrm{Dk}=0.25 \mathrm{~A} / \mathrm{dm}^{2} \quad$ ×ッキ時間 4 分

で䧔極電解研磨(電流密度 1.5

$\mathrm{A} / \mathrm{dm}^{2}$, 研磨時間20秒）した場合は熱カセイソーダ処理 後研磨した場合よりメッキ結果が良いが陽極研磨した場 合は良くない。金属酸塩処理ではマンガン・互鉊クロム 酸㙁処理がよい。

a 銅メッキ

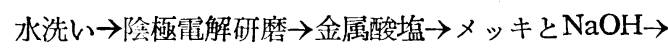

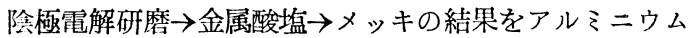
そついてみるとつぎに示すような結果がえられた。

シュラルミンもアルミニウムと同样である。ESD で は亜鉛酸塩のみよい。ジュラルミン, ESD共熱力セイソ 一夕゙処理の際黒色の酸化物で被われるので研磨前に摆硝 酸処理して除去せねばならない。

$\mathrm{b}$ ニッケルメッキ

アルミニウム, ESD ともマンガン, 西䤲酸塩処理がよ く,シュラルミンにはさらにクロム酸塩処理もよい。こ

ジュラルミンの三処理と鍍着洔間

\begin{tabular}{|c|c|c|c|c|c|}
\hline 処 理 & 浴温度 & 0.25 & 0.5 & 0.75 & $\begin{array}{c}1.0 \\
\mathrm{~A} / \mathrm{dm}^{2}\end{array}$ \\
\hline マンガン酸塩 & $\begin{array}{l}10^{\circ} \mathrm{C} \\
20 \\
30\end{array}$ & $\begin{array}{l}8 \sim \text { 分 } \\
7 \sim \\
5 \sim\end{array}$ & $\begin{array}{l}7 \sim \text { 分 } \\
3 \sim \\
3 \sim\end{array}$ & $\begin{array}{l}7 \sim \text { 分 } \\
3 \sim \\
2 \sim\end{array}$ & $\begin{array}{l}5 \\
2 \sim \\
1 \sim\end{array}$ \\
\hline 亜 鉛 酸 塩 & $\begin{array}{l}10 \\
20 \\
30\end{array}$ & $\begin{array}{l}33 \sim \\
23 \sim \\
18 \sim\end{array}$ & $\begin{array}{l}30 \sim \\
22 \sim \\
15 \sim\end{array}$ & $\begin{array}{l}26 \sim \\
18 \sim \\
13 \sim\end{array}$ & $\begin{array}{l}23 \sim \\
15 \sim \\
10 \sim\end{array}$ \\
\hline クロム酸塩 & $\begin{array}{l}10 \\
20 \\
30\end{array}$ & $\left\{\begin{array}{l}13 \sim \\
5 \sim \\
5 \sim\end{array}\right.$ & $\begin{array}{l}10 \sim \\
3 \sim \\
4 \sim\end{array}$ & $\begin{array}{l}7 \sim \\
2 \sim \\
2 \sim\end{array}$ & $\begin{array}{l}4 \sim \\
2 \sim \\
1 \sim\end{array}$ \\
\hline
\end{tabular}

れら三処理液の鍍着に拉よぼす時間はマンガン・クロム 酸塩処理が柜鉊酸塩処理より遥かに短い。

電 解 研磨処理と適否 金順 位
塩

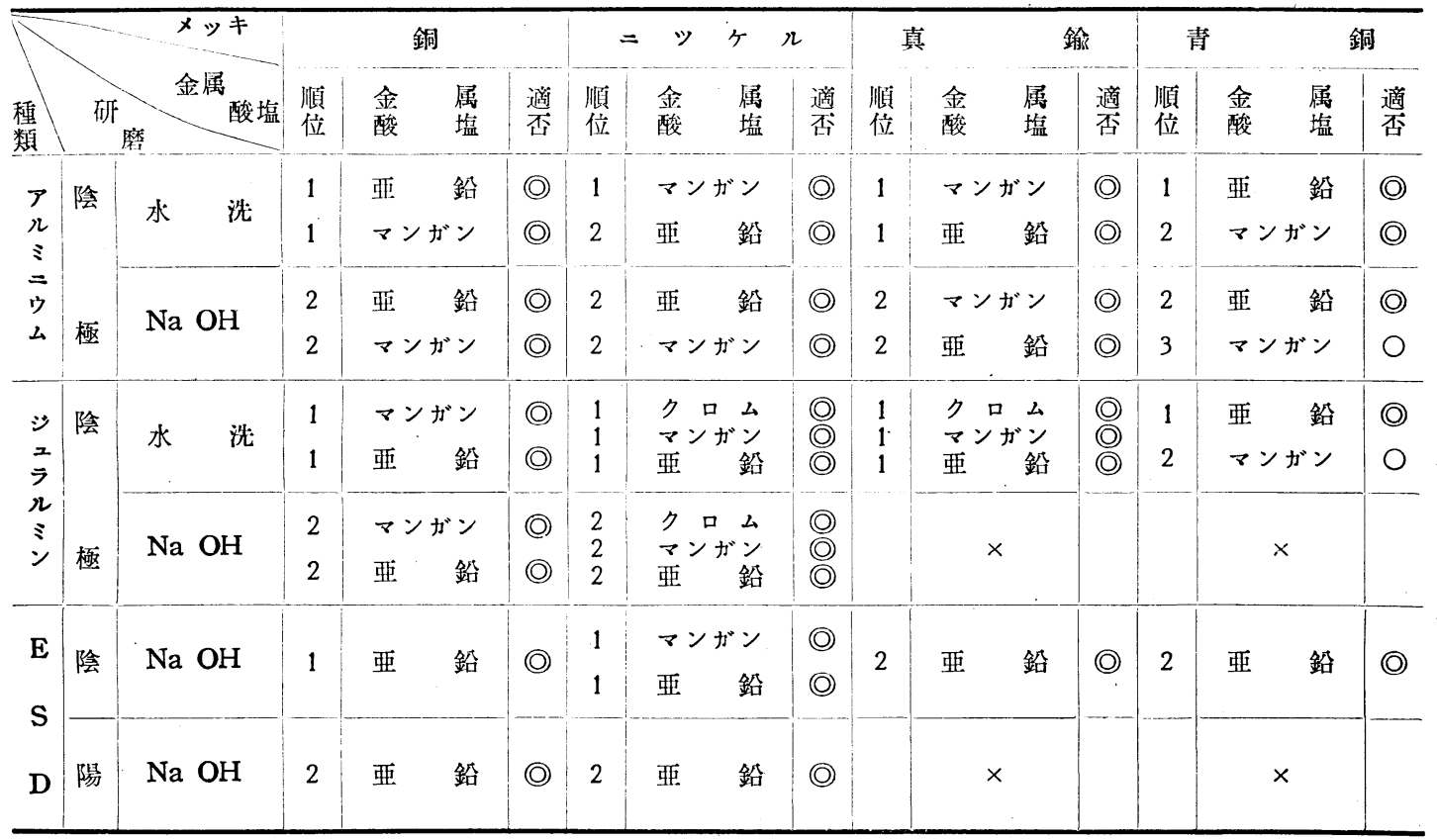


c 真鍮メッキおよび青銅メッキ

アルミニウムシュラルミンには, 亜鉊, マンガン酸塩処 理がよくジュラルミンにクロム酸塩が一般によい。ESD では亜鉊酸塩処理のみがよい。

d $\mathrm{H}_{3} \mathrm{PO}_{4}$ による電解研磨と金属酸塩処理のまとめ,

IVメッキに対する前処理法と考察

a 濃硝酸処理に対する考察

濃硝酸長時間処理が短時間処理より曲げ剝離に強固な 理由は長時間浸清中に電気化学的にとけるためその表面 に凹凸を生じメッキはそれに引掛った状態で鍍着する。

b 亜鉊, マンガン・クロム酸塩処理では金属酸塩中 の金属すなわち亜鉊・マンガン・クロム等とアルミニウ
ムが置換反応を起しその金属がアルミニウムの表面に析 出しメッキはその金属との間で行われる。亜鉊酸塩では

$$
\begin{aligned}
& \mathrm{ZnO}+2 \mathrm{NaOH} \rightarrow \mathrm{Na}_{2} \mathrm{ZnO}_{3}+\mathrm{H}_{2} \mathrm{O} \\
& \mathrm{Na}_{2} \mathrm{ZnO}_{2}+2 \mathrm{Al}+2 \mathrm{H}_{2} \mathrm{O} \rightarrow 2 \mathrm{NaAlO}_{2}+\mathrm{Zn}+\mathrm{H}_{2} \mathrm{O} \\
& \text { マンガン酸塩処理では } \\
& \mathrm{MnO}_{2}+2 \mathrm{NaOH} \rightarrow \mathrm{Na}_{2} \mathrm{MnO}_{3}+\mathrm{H}_{2} \mathrm{O} \\
& 3 \mathrm{Na}_{2} \mathrm{MnO}_{3}+2 \mathrm{Al} \rightarrow 2 \mathrm{Na}_{3} \mathrm{AlO}_{3}+3 \mathrm{Mn}+3(\mathrm{O})
\end{aligned}
$$

c 㓌極電解電解処理と金属酸塩処理, 陰極研磨でア ルミニウム表面の強固な酸化皮膜を還元して金属酸塩と の置換を容易にし金属を析出せしめるためである。陽極 研磨では却って酸化皮膜を生ぜせしめるためメッキは困 難となる。（31.9.3 受理）

\section{アルミペースト用アルミニウム粉末に関する実験}

$$
\text { 麻田宏**.堀口泰 裕* }
$$

\section{A Study on Aluminium Powder in Aluminium Paste}

\section{Hiroshi ASADA Yasuhiro HORIGUCHI}

We investigated the microphotographical figure, rate of reflecting power of light and corrosion registance of aluminium powder contained in aluminium paste (made in England, Germany and Japan), and the following results were obtained.

Small amount of massive particles were observed among the fine leaflike aluminium powder.

The ratio of reflection of "Alpaste" (made in England) was of highest value. By the corrosion test measuring dissolving rate of powder in $5 \%$ hydrochloric acid solution, the powder made in Japan was excellent next came that of Germany and then that of England. However, the effect of organic solvent existed in the paste and size of aluminium powder were out of consideration.

\section{I 緒言}

近時日本扔よび欧米沉扔いてアルミニウム粉末を有機 剤とねり合せたアルペーストを顔料とせる塗料が用いら れるようとなった。これはかなりの耐久性を持つといわ れている。今回の実験沈いてはアルミニウムペースト のアルミニウム粉末について, 光線の反射輝度, 粒子の 形状，扔よび耐食性を試験し，特に英国製品と他社の製 品を比較してみた。な招本実験前と各粉末は一定時間 $100^{\circ} \mathrm{C}$ 以下の低温処理とより有機剤を飛散せしめた。

\begin{tabular}{|c|c|c|c|c|c|c|}
\hline 粉 & $\begin{array}{l}\text { 日本 製 } \\
200 \times ッ シ ュ\end{array}$ & $250 \times \stackrel{\text { 同 }}{*}$ シ & $325 \times \stackrel{\text { 同 }}{*}$ × & 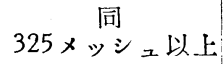 & 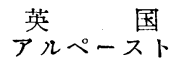 & $\begin{array}{c}\text { ドイツ製 } \\
\text { アミペースト }\end{array}$ \\
\hline 反射のヨミ & 70 & 53 & 87 & 85 & 90 & 80 \\
\hline
\end{tabular}

\section{II 試験材料および試験方法}

実験せる粉末は, 日本製三科印 \#600・200メッシュ,

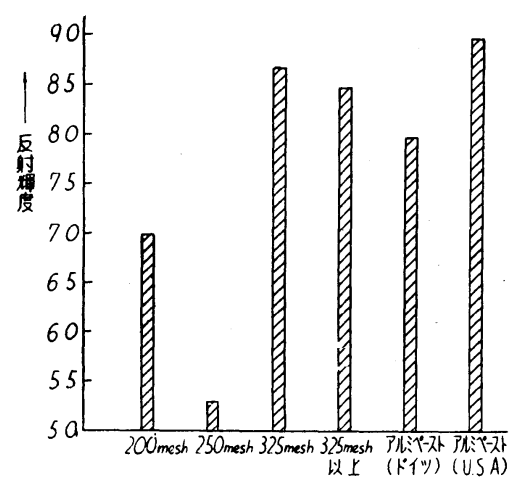

第1図 NF計飞よる結果

第 1 表 N F 計 飞よる 結 果

* 東京大学理工学研究所 